\title{
IV Międzynarodowa Konferencja Naukowa Pogranicza: kontakty kulturowe, literackie, językowe, Supraśl 16-17.10.2017
}

$\mathrm{W}$

dniach 16-17 października 2017 r. odbyła się w Supraślu IV Międzynarodowa Konferencja Naukowa Pogranicza: kontakty kulturowe, literackie, językowe. Sympozjum zorganizowała Katedra Językoznawstwa Wschodniosłowiańskiego Uniwersytetu w Białymstoku przy współudziale Katedry Językoznawstwa Ogólnego i Słowiańskiego Uniwersytetu Państwowego im. Janki Kupały w Grodnie. Komitetowi organizacyjnemu przewodniczyła prof. dr hab. Leonarda Dacewicz, w jego składzie zaś znalazły się: dr Elżbieta Bogdanowicz, dr Inna Lisowska oraz dr Walentyna Mieszkowska. W konferencji wzięli udział naukowcy reprezentujący siedem ośrodków krajowych: Białystok, Bydgoszcz, Kraków, Lublin, Olsztyn, Siedlce, Warszawę, oraz sześć zagranicznych: Grodno, Mińsk, Witebsk (Białoruś), Kijów (Ukraina), Kutaisi (Gruzja), Lille (Francja). W trakcie obrad (na forum plenarnym oraz w dwóch sekcjach) wygłoszono 30 referatów.

Znaczna część wystąpień dotyczyła tematyki onomastycznej. Prelegenci omawiali różnorakie zagadnienia związane m.in. z: antroponimią, etnonimią, chrematonimią, mikrotoponimią, wikonimią. Szczególnie interesujące i wzbudzające uwagę słuchaczy było wystąpienie prof. dr hab. Leonardy Dacewicz (Uniwersytet w Białymstoku), które zostało poświęcone etnonimom россияне, русские w opracowaniach leksykograficznych w przekroju historycznym. Tematem nie mniej inspirującego referatu dr Elżbiety Bogdanowicz (Uniwersytet w Białymstoku) były nazwy własne jako podstawa struktur skontaminowanych. Referentka omówiła je, wykorzystując materiał języka polskiego i rosyjskiego. Kolejna uczestniczka konferencji prof. Anna Miezienko (Witebski Uniwersytet Państwowy im. P.M. Maszerowa) poruszyła bardzo interesującą tematykę specyfiki nominacji aptek, zwracając uwagę na terytorialne aspekty ich zróżnicowania semantycznego. Z kolei wystąpienie doc. Mariny Dorofiejenki (Witebski Uniwersytet Państwowy im. P.M. Maszerowa) poświęcone było osobliwościom nominacyjnym wikonimii pogranicza białorusko-rosyjskiego. Referaty dr Aliny Filinowicz (Uniwersytet w Białymstoku) i mgr Anny Mikiciuk (Uniwersytet Marii Curie-Skłodowskiej w Lublinie) dotyczyły tematyki mikrotoponimii pogranicza polsko-wschodniosłowiańskiego. Pierwsza z prelegentek skoncentrowała się na przedstawieniu uczestnikom konferencji problematyki występowania litewskiego rdzenia var- w mikrotoponimii pogranicza polsko-białoruskiego, druga zaś przybliżyła słuchaczom tematykę różnych aspektów nazewnictwa obiektów terenowych w powiecie Biała Podlaska. Kolejne dwa wystąpienia dotyczyły zagadnień z zakresu antroponimii. 
Dr Henryk Duszyński-Karabasz (Uniwersytet Kazimierza Wielkiego w Bydgoszczy) scharakteryzował typy i sposoby tworzenia nazw osobowych na materiale inskrypcji nagrobnych cmentarza komunalnego przy ul. Kcyńskiej w Bydgoszczy, zwracając przy tym szczególną uwagę na nazwy pochodzenia wschodniosłowiańskiego, natomiast dr Piotr Złotkowski (Uniwersytet Marii Curie-Skłodowskiej w Lublinie) poddał analizie nazwiska historyczne chłopów z okolic Brańska na Podlasiu motywowane apelatywami przychodzy, zachodzy. Interesujące wystąpienie dra hab. Władimira Miakiszewa (Uniwersytet Jagielloński w Krakowie) przybliżyło problemy związane ze stabilizacją formy imienia znanego podróżnika i odkrywcy Amerigo Vespucciego w kronikach słowiańskich XVI stulecia. W ich wyniku, zdaniem prelegenta, mogło dojść do ukształtowania się miana kontynentu, który obecnie znamy pod nazwą Ameryki, od wariantu jego imienia w postaci Alberyk („A mogła być Alberyka”...).

Duża część prelekcji dotyczyła różnych aspektów badań językoznawczych (m.in. zagadnień: semantyki, słowotwórstwa, tekstologii, translatoryki itp.). Wypowiedź doc. Ludmiły Czernyszowej (Miński Państwowy Uniwersytet Lingwistyczny) koncentrowała się na tematyce semantyki gniazda słowotwórczego. Dr Jelena Sadowskaja (Grodzieński Uniwersytet Państwowy im. Janki Kupały) omówiła stałe jednostki językowe wspólne dla języków wschodniosłowiańskich w aspekcie semantyczno-gramatycznym. Przedmiotem wystąpienia dr Anny Żurawlowej (Université Lille 3) była natomiast specyfika lingwistycznej strefy pogranicznej między Białorusią a Rosją. Z kolei referat prof. Manany Mikadze (Państwowy Uniwersytet im. Akaki Cereteli w Kutaisi) dotyczył realizacji modalności w wyniku semantyzacji fragmentów tekstu. Dr Joanna Nawacka (Uniwersytet Warmińsko-Mazurski w Olsztynie) przedstawiła zagadnienie przekładu konceptu wartość z języka rosyjskiego na język polski. Problematyka normy językowej wobec neologizmów leksykalnych we współczesnej ruszczyźnie była przedmiotem referatu dr Anny Romanik (Uniwersytet w Białymstoku). Doc. Zoja Sidorowicz (Grodzieński Uniwersytet Państwowy im. Janki Kupały) zapoznała uczestników konferencji z intertekstualnością jako kategorią tekstu w eseju A.G. Bitowa Русский устный и русский письменный. Wystąpienie dr Joanny Joachimiak-Prażanowskiej (Uniwersytet Kazimierza Wielkiego w Bydgoszczy) koncentrowało się na zjawiskach z zakresu konsonantyzmu w międzywojennej polszczyźnie północnokresowej (na materiale „Kuriera Wileńskiego”).

Relacja media-język znalazła odzwierciedlenie w odczytach dr Joanny Wasiluk (Uniwersytet Warszawski) i dr Eugenii Maksimowicz (Uniwersytet w Białymstoku). Pierwsza z referentek poddała analizie leksykalne formy oddziaływania językowego wykorzystywane w prasie polskiej i rosyjskiej (na przykładzie „Gazety Wyborczej” i gazety „Известия”), druga przedstawiła problem wykorzystania frazeologizmów o etymologii biblijnej we współczesnych rosyjskich środkach masowego przekazu.

Szeroko pojęte zagadnienia dawnego piśmiennictwa rusko- i rosyjskojęzycznego poruszone zostały w trzech wystąpieniach. Dr hab. Anna Bolek (Uniwersytet Przyrodniczo-Humanistyczny w Siedlcach) mówiła o walorach poznawczych i recepcji wśród mieszkańców Rusi Moskiewskiej przekładu Peregrynacji do Ziemi Świętej księcia Ra- 
dziwitła Sierotki. Tematem odczytu dr hab. Joanny Getki (Uniwersytet Warszawski) była problematyka ruskojęzycznych bazyliańskich teologii moralnych XVIII stulecia w kontekście postanowień Synodu Zamojskiego. Z kolei dr Olga Anchimiuk (Uniwersytet w Białymstoku) przedstawiła słuchaczom zagadnienie opozycji binarnych w opisach cross-dressingu w tekście Жития преподобной матери натей Пелагии.

Prelekcje doc. Anny Szwiec i doc. Myrosławy Szewczenko (Kijowski Uniwersytet Narodowy im. Tarasa Szewczenki) przybliżyły słuchaczom problematykę glottodydaktyczną. Pierwsza koncentrowała się na kwestii wykorzystania tekstów współczesnej eseistyki w nauczaniu cudzoziemców języka ukraińskiego, w drugiej poruszono problem interferencji oraz sposobów jej przezwyciężania w procesie nauczania języka ukraińskiego przez polskich studentów.

Uczestnicy konferencji wysłuchali również trzech referatów literaturoznawczych. Prof. Nino Kwirikadze (Państwowy Uniwersytet im. Akaki Cereteli w Kutaisi) podjęła temat małego człowieka w twórczości Walerija Briusowa i Tomasza Manna na podstawie utworów Bemol i Mały pan Friedemann. O tożsamości rosyjskiej literatury emigracyjnej na podstawie prozy Nadieżdy Teffi mówiła dr hab. Iwona Anna Ndiaye (Uniwersytet Warmińsko-Mazurski). Z kolei dr Jolanta Chomko (Uniwersytet w Białymstoku) w interesującym wystąpieniu poruszyła temat palety barw achromatycznych w Szkarłatnych żaglach Aleksandra Grina.

$\mathrm{Na}$ sympozjum wygłoszono także prelekcje o tematyce ekstralingwistycznej. Ks. dr Adam Bielinowicz (Uniwersytet Warmińsko-Mazurski w Olsztynie) omówił kontakty kulturowe pogranicza polsko-litewskiego na przykładzie działalności Towarzystwa Przyjaciół Ziemi Wileńsko-Nowogródzkiej w Szczytnie. Wystąpienie ks. dra Zbigniewa Stępniaka (Uniwersytet Warmińsko-Mazurski w Olsztynie) dotyczyło koncertów muzycznych jako formy współpracy socjalno-kulturowej. Tematem referatu mgr Justyny Matus (Uniwersytet w Białymstoku) był kult ikon na pograniczu polsko-wschodniosłowiańskim.

Jak wynika z powyższego omówienia, zakres tematów poruszanych na konferencji był szeroki. Obejmował wachlarz zagadnień odnoszących się do specyfiki pogranicza, analizowanej na poziomie języka, literatury i kultury. Nie zabrakło również wystąpień wychodzących poza ramy głównego nurtu sympozjum. Niewątpliwymi atutami konferencji były jej wysoki poziom naukowy oraz bardzo dobra organizacja. Tego typu przedsięwzięcia stanowią świadectwo współpracy środowiska językoznawców polskich i białoruskich. Wypada mieć nadzieję, że w przyszłości będzie ona kontynuowana, co zaowocuje kolejnymi konferencjami. Warto jeszcze zwrócić uwagę na szczególny supraski genius loci, który czyni to miasto idealnym miejscem do prezentowania rezultatów badań naukowych. 